\title{
Pheromone-plant interaction in Heliothis virescens
}

\author{
Elisa Badeke ${ }^{1 *}$, Pablo Pregitzer², Bill S. Hansson', Jürgen Krieger², Silke Sachse ${ }^{1}$ \\ From 1st International Workshop on Odor Spaces \\ Hannover, Germany. 4-7 September 2013
}

Insects are exposed to a complex environment consisting of a wide range of different odors. The information content of a certain odor bouquet, which is perceived by an insect, is essential for preventing predators, finding oviposition sites, navigation, foraging and mating. In the latter case, pheromone detection and processing is crucial for an insect to find its conspecific sexual partner. Because of their extremely specialized pheromone detection appendages, the antennae, moths are the most used model organisms to investigate the function of the pheromone system. In the noctoid moth, Heliothis virescens, we could demonstrate that plant volatiles interfere with pheromone responses at the level of the olfactory sensory neurons (OSN). By in vivo calcium imaging we stimulated simultaneously with the major sex pheromone component of $\mathrm{H}$. virescens, Z11-16:Ald, and plant-related odorants. The results show that plant odorants significantly suppress Z11-16:Ald-evoked activity in the magroglomerular complex, where Z11-16:Ald-tuned OSNs terminate. These findings indicate that the effect of an odor background is important for the complex mechanism of pheromone detection and coding.

Furthermore, we aim to decipher how a plant odor background influences pheromone-guided flight behavior. We are in the process of performing wind tunnel experiments to analyze the interaction of pheromone components and plant volatiles at the behavioral level in order to mimic the natural situation.

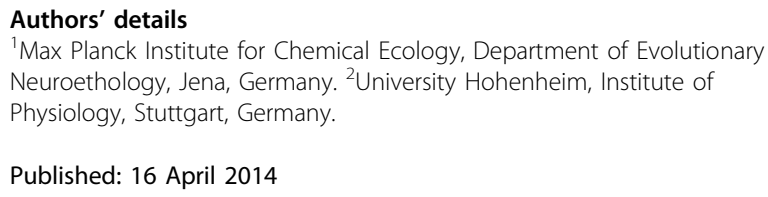

'Max Planck Institute for Chemical Ecology, Department of Evolutionary Neuroethology, Jena, Germany

Full list of author information is available at the end of the article
doi:10.1186/2044-7248-3-S1-P2

Cite this article as: Badeke et al:: Pheromone-plant interaction in Heliothis virescens. Flavour 2014 3(Suppl 1):P2.
Submit your next manuscript to BioMed Central and take full advantage of:

- Convenient online submission

- Thorough peer review

- No space constraints or color figure charges

- Immediate publication on acceptance

- Inclusion in PubMed, CAS, Scopus and Google Scholar

- Research which is freely available for redistribution
C Biomed Central

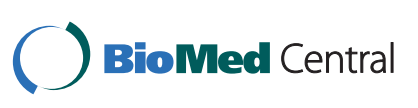

(c) 2014 Badeke et al; licensee BioMed Central Ltd. This is an Open Access article distributed under the terms of the Creative Commons Attribution License (http://creativecommons.org/licenses/by/2.0), which permits unrestricted use, distribution, and reproduction in any medium, provided the original work is properly cited. The Creative Commons Public Domain Dedication waiver (http:// creativecommons.org/publicdomain/zero/1.0/) applies to the data made available in this article, unless otherwise stated. 